
78 巻 790 号 2012-6)

\title{
フラフープとアシストモータを用いた制振*
}

吉武 裕*1, 清水 亮佑*2, 梶原 修平*3 柴原 文高*4，宮川 史也 ${ }^{* 5}$ ，原田 晃 ${ }^{* 1}$

\section{Vibration Control Using Hula-Hoop and Assistant Motor}

\author{
Yutaka YOSHITAKE* ${ }^{*}$, Ryosuke SHIMIZU, Shuhei KAJIHARA \\ Fumitaka SHIBAHARA, Humiya MIYAGAWA and Akira HARADA \\ ${ }^{* 1}$ Graduate School of Engineering, Nagasaki University \\ Bunkyo-machi 1-14, Nagasaki-shi, Nagasaki, 852-8521 Japan
}

This paper deals with the problem of vibration quenching of the system with a limited power supply using a Hula-Hoop and a motor to assist its rotation. Quenching of horizontal vibration of the one-degree-of-freedom system forced by centrifugal force of unbalance is researched. Following was made clear from the numerical analysis, the approximate analysis using the averaging method, and the experiment: (1) By cancelling the rotational resistance of the Hula-Hoop using an assistant motor, the amplitude of the main system becomes zero theoretically. (2) In the case that the power source and the torque assist equipment are both motors, the optimal voltage for the assistant motor to quench the main system vibration perfectly is obtained from the approximate analysis using the averaging method. (3) The results obtained by the averaging method and those obtained by the numerical integration were in good agreement not only qualitatively but also quantitatively, and those results and that obtained by the experiment were in good agreement qualitatively.

Key Words: Nonlinear Vibration, Vibration Control Device, Forced Vibration, Hula-Hoop, Autoparametric Excitation

\section{1. 緒言}

パッシブな制振装置の 1 つに自動平衡装置がある ${ }^{(1)(2)}$.これは制振対象の機械とともに回転する浅い円筒容 器の中に転動球を入れることにより転動球が自動的にバランスをとる装置である。この装置は共振点より高 い振動数領域で用いられ，大きな制振効果を持つが，その振動数領域で転動球がアンバランスと釣り合う位 置に配置されず, 自励振動が発生する可能性があり, また, 共振点より低い振動数では, アンバランスと同 じ側に配置され，振幅を増加させてしまうなどの欠点がある。これに対し，著者らはフラフープの運動の原 理を利用した制振装置を提案してきた ${ }^{(3)}$ (7). そして, この装置では, 自動平衡装置のような自励振動が発生

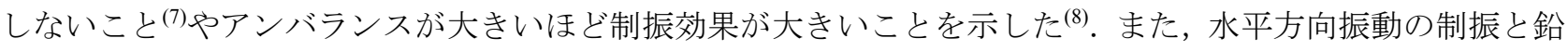
直方向振動の制振の相違を明らかにした ${ }^{(8)}$. さらに，フラフープ回転時の抵抗が制振効果に悪影響を及ぼし ていることが明らかになった ${ }^{(8)}$ ，そこで，本報では，補助モータを用いることによりフラフープの回転抵抗 を打ち消寸機能を追加したフラフープと補助モータからなる制振装置を機械構造物に取り付けた場合の制振 効果を理論解析と実験により調べる.

\footnotetext{
* 原稿受付 2011 年 10 月 24 日

*1 正員, 長崎大学大学院工学研究科（广852-8521 長崎県長崎市文教町 1-14）

*2 長崎大学大学院生産科学研究科

*3 正員, 三井造船 (株)（广706-8651 岡山県玉名市玉 3-1-1）

*4 正員, 三菱重工 (株)（干850-8610 長崎県長崎市飽の浦町 1-1）

*5 長崎大学大学院工学研究科

E-mail:yoshitak@nagasaki-u.ac.jp
} 


\section{2. 解析モデルと運動方程式}

図 1 に解析モデルを示す，図 1 の図(a)は正面図であり, 図(b)にはアンバランスとフラフープの座標を示し ている（添字 $i=0$ がアンバランス， $i=2$ がフラフープを意味する）。一自由度振動系（主系）に動力源モー タが内蔵され, 質量 $m_{0}$ のアンバランスが取り付けられている. 主系はアンバランスの回転による遠心力によ って加振されるが, 制振装置として, 質量 $m_{2}$ のフラフープとその回転抵抗トルクを打ち消寸ためのトルクを 補助するモータ（以下，アシストモータと呼ぶ）を取り付けている. 図 2 に動力源モータの等価回路, 図 3 にアシストモータの等価回路を示寸。このとき, 主系, アンバランス, フラフープの運動方程式はそれぞれ 以下のようになる.

$$
\begin{aligned}
& \left(m_{0}+m_{1}+m_{2}\right) \ddot{x}+c_{1} \dot{x}+k_{1} x-m_{0} l_{\mathrm{G} 0}\left(\ddot{\theta}_{0} \sin \theta_{0}+\dot{\theta}_{0}^{2} \cos \theta_{0}\right)-m_{2} l_{\mathrm{G} 2}\left(\ddot{\theta}_{2} \sin \theta_{2}+\dot{\theta}_{2}^{2} \cos \theta_{2}\right)=0 \\
& \left(I_{\mathrm{GM} 0}+I_{\mathrm{G} 0}+m_{0} l_{\mathrm{G} 0}{ }^{2}\right) \ddot{\theta}_{0}-m_{0} l_{\mathrm{G} 0} \ddot{x} \sin \theta_{0}=K_{\mathrm{T} 0} I_{0}-N_{0} \dot{\theta}_{0} \\
& \left(I_{\mathrm{GM} 2}+I_{\mathrm{G} 2}+m_{2} l_{\mathrm{G} 2}{ }^{2}\right) \ddot{\theta}_{2}-m_{2} l_{\mathrm{G} 2} \ddot{x} \sin \theta_{2}=K_{\mathrm{T} 2} I_{2}-N_{2} \dot{\theta}_{2}
\end{aligned}
$$

また，主系の動力源モータとアシストモータの状態方程式は次式となる(7).

$$
\begin{aligned}
& L_{0} \dot{I}_{0}=-K_{\mathrm{E} 0} \dot{\theta}_{0}-R_{0} I_{0}+E_{0} \\
& L_{2} \dot{I}_{2}=-K_{\mathrm{E} 2} \dot{\theta}_{2}-R_{2} I_{2}+E_{2}
\end{aligned}
$$

ここに, モータはいずれも DC モータを用いており, 動力源モータのトルクは式(2)の右辺であり, アシスト モータのトルクは式(3)の右辺である. 各パラメータは以下のように定義されている.
$x \quad$ : 主系の変位
$\theta_{2} \quad$ : フラフープの回転角
$\theta_{0} \quad$ : アンバランスの回転角
$m_{1} \quad$ : 主系の質量

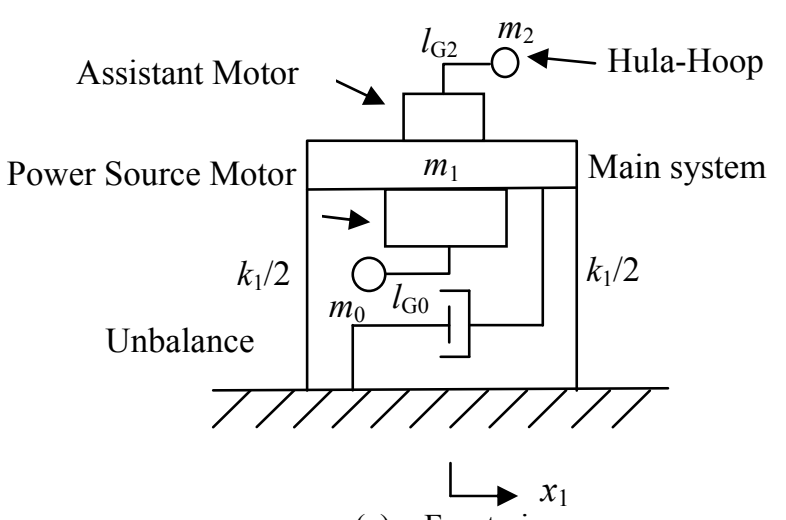

(a) Front view

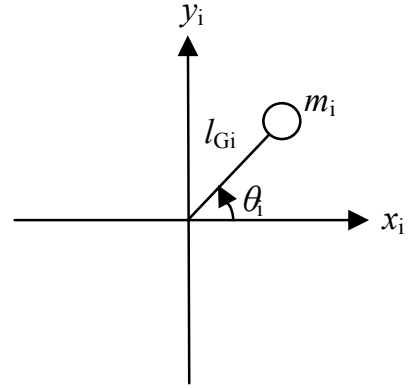

(b) Coordinates of unbalance and Hula-Hoop

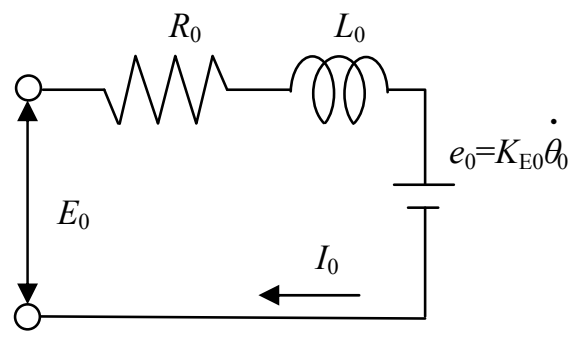

Fig.2 Electric circuit of power source motor

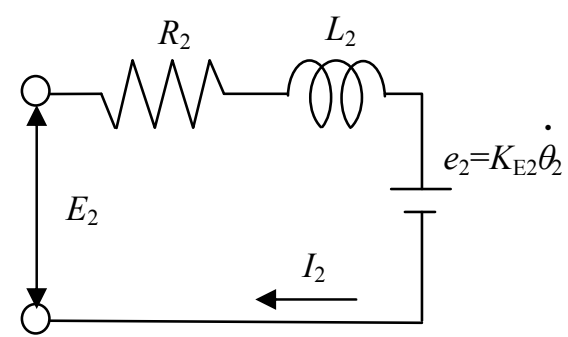

Fig.3 Electric circuit of assist motor 


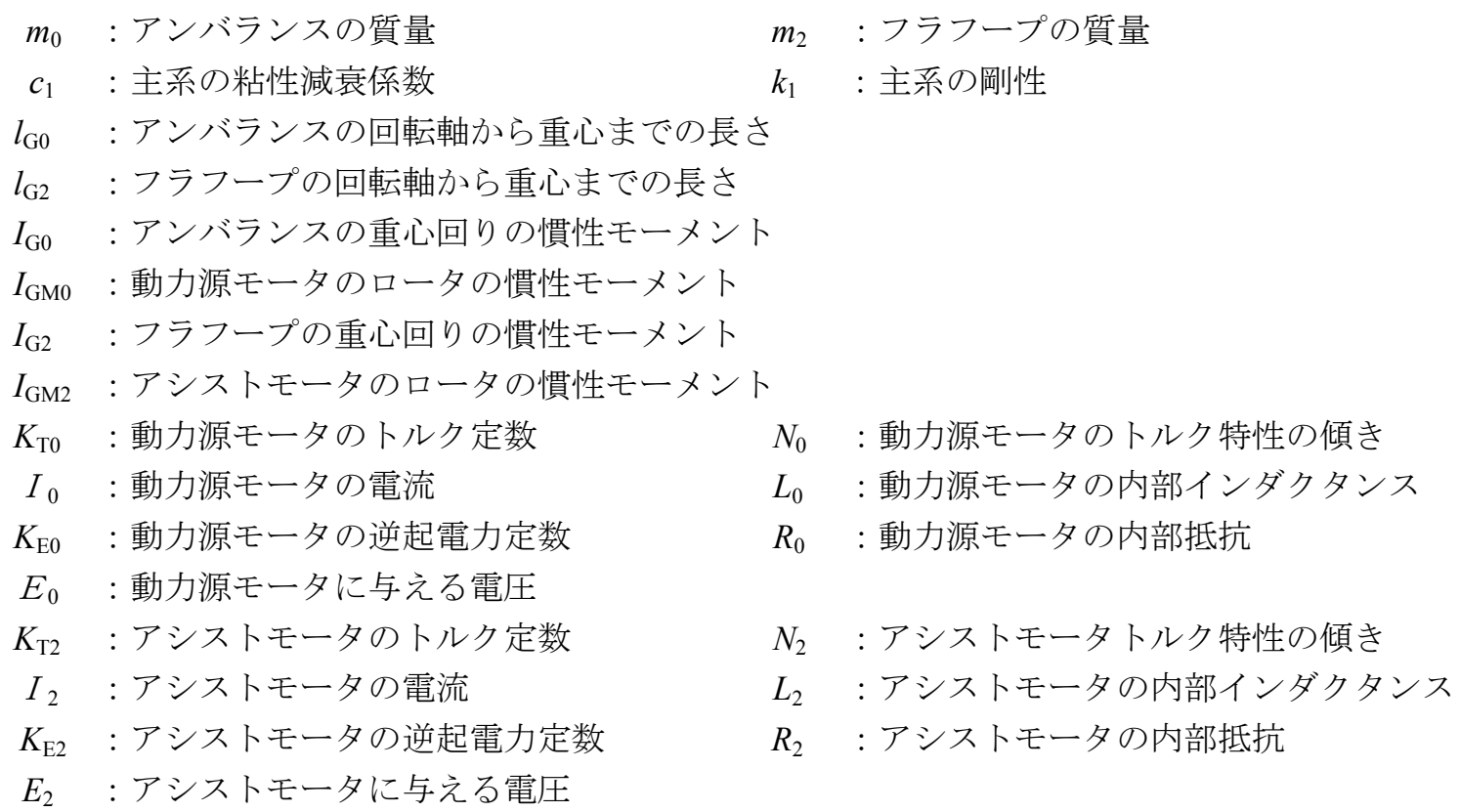

\section{3. 平均法による近似解}

\section{$3 \cdot 1$ 定常解}

本節では, 前章で示した運動方程式に平均法を適用し, 近似解を求める. また, 得られた定常解について 解の安定判別を行う.

主系の角振動数を $\omega$ とし，主系の固有振動数よりも高い振動数でアンバランスが回転しているときを扱う ものとし, 復元力の項を省略するとともに, 減衰力も小さいものとして, 減衰力の項も省略すると, 式(1)は 次式となる.

$$
\ddot{x}=\frac{1}{m_{0}+m_{1}+m_{2}}\left\{m_{0} l_{\mathrm{G} 0}\left(\ddot{\theta}_{0} \sin \theta_{0}+\dot{\theta}_{0}^{2} \cos \theta_{0}\right)+m_{2} l_{\mathrm{G} 2}\left(\ddot{\theta}_{2} \sin \theta_{2}+\dot{\theta}_{2}^{2} \cos \theta_{2}\right)\right\}
$$

式(4)〜(6)を式(2)，(3)に代入すると次式を得る.

$$
\begin{aligned}
& \left(I_{\mathrm{GM} 0}+I_{\mathrm{G} 0}+m_{0} l_{\mathrm{G} 0}{ }^{2}\right) \ddot{\theta}_{0}-\frac{m_{0} l_{\mathrm{G} 0}}{m_{0}+m_{1}+m_{2}}\left\{\begin{array}{c}
m_{0} l_{\mathrm{G} 0}\left(\ddot{\theta}_{0} \sin \theta_{0}+\dot{\theta}_{0}{ }^{2} \cos \theta_{0}\right) \\
+m_{2} l_{\mathrm{G} 2}\left(\ddot{\theta}_{2} \sin \theta_{2}+\dot{\theta}_{2}{ }^{2} \cos \theta_{2}\right)
\end{array}\right\} \sin \theta_{0} \\
& =-\frac{K_{\mathrm{T} 0}}{R_{0}}\left(L_{0} \dot{I}_{0}+K_{\mathrm{E} 0} \dot{\theta}_{0}-E_{0}\right)-N_{0} \dot{\theta}_{0} \\
& \left(I_{G M 2}+I_{\mathrm{G} 2}+m_{2} l_{\mathrm{G} 2}{ }^{2}\right) \ddot{\theta}_{2}-\frac{m_{2} l_{\mathrm{G} 2}}{m_{0}+m_{1}+m_{2}}\left\{\begin{array}{c}
m_{0} l_{\mathrm{G} 0}\left(\ddot{\theta}_{0} \sin \theta_{0}+\dot{\theta}_{0}{ }^{2} \cos \theta_{0}\right) \\
+m_{2} l_{\mathrm{G} 2}\left(\ddot{\theta}_{2} \sin \theta_{2}+\dot{\theta}_{2}{ }^{2} \cos \theta_{2}\right)
\end{array}\right\} \sin \theta_{2} \\
& =-\frac{K_{\mathrm{T} 2}}{R_{2}}\left(L_{2} \dot{I}_{2}+K_{\mathrm{E} 2} \dot{\theta}_{2}-E_{2}\right)-N_{2} \dot{\theta}_{2}
\end{aligned}
$$

フラフープとアンバランスがそれぞれ位相角 $\varphi_{0}, \varphi_{2}$ で同方向に角速度 $\omega$ で回転しているとすると

$$
\dot{\theta}_{0}=\omega+\frac{d \varphi_{0}}{d t}, \quad \dot{\theta}_{2}=\omega+\frac{d \varphi_{2}}{d t}, \quad \ddot{\theta}_{0}=\frac{d^{2} \varphi_{0}}{d t^{2}}, \quad \ddot{\theta}_{2}=\frac{d^{2} \varphi_{2}}{d t^{2}}
$$

となる. 式(9)を式(7), (8)に代入した後， $\varphi_{0}$ と $\varphi_{2}$ が時間と共に緩やかに変化する関数であることを考慮し， 1 周期間積分すると次式を得る. 


$$
\begin{array}{r}
\left(I_{\mathrm{GM} 0}+I_{\mathrm{G} 0}+m_{0} l_{\mathrm{G} 0}{ }^{2}\right) \frac{d^{2} \varphi_{0}}{d t^{2}} \\
-\frac{m_{0} l_{\mathrm{G} 0}}{m_{0}+m_{1}+m_{2}}\left[m_{0} l_{\mathrm{G} 0}\left(\frac{d^{2} \varphi_{0}}{d t^{2}} \times \frac{1}{2}\right)+m_{2} l_{\mathrm{G} 2}\left\{\begin{array}{c}
\frac{d^{2} \varphi_{2}}{d t^{2}} \times \frac{1}{2} \cos \left(\varphi_{0}-\varphi_{2}\right) \\
\left.+\left(\omega+\frac{d \varphi_{2}}{d t}\right)^{2} \times \frac{1}{2} \sin \left(\varphi_{0}-\varphi_{2}\right)\right)
\end{array}\right\}\right] \\
=-\frac{K_{\mathrm{T} 0}}{R_{0}}\left\{L_{0} \dot{I}_{0}+K_{\mathrm{E} 0}\left(\omega+\frac{d \varphi_{0}}{d t}\right)-E_{0}\right\}-N_{0}\left(\omega+\frac{d \varphi_{0}}{d t}\right) \\
\left(I_{G M 2}+I_{\mathrm{G} 2}+m_{2} l_{\mathrm{G} 2}{ }^{2}\right) \frac{d^{2} \varphi_{2}}{d t^{2}} \\
-\frac{m_{2} l_{\mathrm{G} 2}}{m_{0}+m_{1}+m_{2}}\left[\begin{array}{r}
m_{0} l_{\mathrm{G} 0} \\
\left.\begin{array}{c}
\frac{d^{2} \varphi_{0}}{d t^{2}} \times \frac{1}{2} \cos \left(\varphi_{2}-\varphi_{0}\right) \\
+\left(\omega+\frac{d \varphi_{0}}{d t}\right)^{2} \times \frac{1}{2} \sin \left(\varphi_{2}-\varphi_{0}\right)
\end{array}\right\}+m_{2} l_{\mathrm{G} 2}\left(\frac{d^{2} \varphi_{2}}{d t^{2}} \times \frac{1}{2}\right) \\
=-\frac{K_{\mathrm{T} 2}}{R_{2}}\left\{L_{2} \dot{I}_{2}+K_{\mathrm{E} 2}\left(\omega+\frac{d \varphi_{2}}{d t}\right)-E_{2}\right\}-N_{2}\left(\omega+\frac{d \varphi_{2}}{d t}\right)
\end{array}\right.
\end{array}
$$

アンバランスとフラフープが同じ角速度で定常回転し, また, 動力源モータ, アシストモータに流れる電 流が一定であるとして,

$$
\frac{d^{2} \varphi_{0}}{d t^{2}}=0, \quad \frac{d^{2} \varphi_{2}}{d t^{2}}=0, \quad \frac{d \varphi_{0}}{d t}=0, \quad \frac{d \varphi_{2}}{d t}=0, \quad \dot{I}_{0}=0, \quad \dot{I}_{2}=0
$$

と置き, 定常状態において, $\varphi_{0}=\varphi_{00}, \varphi_{2}=\varphi_{20}$ とすると, 式(10), 式(11)から次式を得る.

$$
\begin{aligned}
& \frac{m_{0} l_{\mathrm{G} 0} m_{2} l_{\mathrm{G} 2} \omega^{2}}{2\left(m_{0}+m_{1}+m_{2}\right)} \sin \left(\varphi_{00}-\varphi_{20}\right)=\left(\frac{K_{\mathrm{T} 0} K_{\mathrm{E} 0}}{R_{0}}+N_{0}\right) \omega-\frac{K_{\mathrm{T} 0} E_{0}}{R_{0}} \\
& \frac{m_{0} l_{\mathrm{G} 0} m_{2} l_{\mathrm{G} 2} \omega^{2}}{2\left(m_{0}+m_{1}+m_{2}\right)} \sin \left(\varphi_{20}-\varphi_{00}\right)=\left(\frac{K_{\mathrm{T} 2} K_{\mathrm{E} 2}}{R_{2}}+N_{2}\right) \omega-\frac{K_{\mathrm{T} 2} E_{2}}{R_{2}}
\end{aligned}
$$

式(13)，式(14)から主系の振動数，アンバランスとフラフープの位相差の関係は次式となる.

$$
\begin{aligned}
& \omega=\frac{K_{\mathrm{T} 0} E_{0} R_{2}+K_{\mathrm{T} 2} E_{2} R_{0}}{K_{\mathrm{T} 0} K_{\mathrm{E} 0} R_{2}+K_{\mathrm{T} 2} K_{\mathrm{E} 2} R_{0}+\left(N_{0}+N_{2}\right) R_{0} R_{2}} \\
& \sin \left(\varphi_{00}-\varphi_{20}\right)=\frac{2\left(m_{0}+m_{1}+m_{2}\right)\left\{\left(K_{T 0} K_{E 0}+N_{0} R_{0}\right) \omega-K_{T 0} E_{0}\right\}}{R_{0} m_{0} l_{G 0} m_{2} l_{G 2} \omega^{2}}
\end{aligned}
$$

次に, このときの主系の振幅を考える. 定常状態のとき, $\dot{\varphi}_{00}=\omega, \ddot{\varphi}_{00}=0, \dot{\varphi}_{20}=\omega, \quad \ddot{\varphi}_{20}=0$ であるから, 式(6)から次式を得る.

$$
\ddot{x}=\frac{\omega^{2}}{m_{0}+m_{1}+m_{2}}\left\{m_{0} l_{\mathrm{G} 0} \cos \left(\omega t+\varphi_{0}\right)+m_{2} l_{\mathrm{G} 2} \cos \left(\omega t+\varphi_{2}\right)\right\}
$$

また, 主系の変位振幅を求めるために, 変位振幅を $a_{1}$, 位相を $\Theta$ とて, 加速度を 
$\ddot{x}=-a_{1} \omega^{2} \cos (\omega t+\Theta)$

とおくと, 式(15)〜式(17)から主系の変位振幅の定常解を決定する式

$$
a_{1}^{2}=\frac{1}{\left(m_{0}+m_{1}+m_{2}\right)^{2}}\left\{\left(m_{0} l_{G 0}\right)^{2}+\left(m_{2} l_{\mathrm{G} 2}\right)^{2} \pm 2 m_{0} l_{G 0} m_{2} l_{\mathrm{G} 2} \sqrt{1-\sin ^{2}\left(\varphi_{00}-\varphi_{20}\right)}\right\}
$$

が得られる。

\section{$3 \cdot 2$ 定常解の安定判別}

次に, 定常解の安定判別を行う。定常解からの小さな外乱を $\xi, \eta$ とし

$$
\varphi_{0}=\varphi_{00}+\xi, \quad \varphi_{2}=\varphi_{20}+\eta
$$

とおき, 高次の微小量を省略するとともに, $\dot{I}_{0}=0, \dot{I}_{2}=0$ とおくと, 式(10), (11)から次式を得る.

$$
\begin{aligned}
& K\left(\omega^{2}+2 \omega \frac{d \eta}{d t}\right)\{\sin \Phi+(\xi-\eta) \cos \Phi\}-\frac{K_{\mathrm{T} 0}}{R_{0}}\left\{K_{\mathrm{E} 0}\left(\omega+\frac{d \xi}{d t}\right)-E_{0}\right\}-N_{0}\left(\omega+\frac{d \xi}{d t}\right)=0 \\
& K\left(\omega^{2}+2 \omega \frac{d \xi}{d t}\right)\{\sin \Phi-(\eta-\xi) \cos \Phi\}+\frac{K_{T 2}}{R_{2}}\left\{K_{E 2}\left(\omega+\frac{d \eta}{d t}\right)-E_{2}\right\}+N_{2}\left(\omega+\frac{d \eta}{d t}\right)=0
\end{aligned}
$$

ここに,

$$
\Phi=\varphi_{00}-\varphi_{20}, \quad K=\frac{m_{0} l_{\mathrm{G} 0} m_{2} l_{\mathrm{G} 2}}{2\left(m_{0}+m_{1}+m_{2}\right)}
$$

定常解の条件式である式(13)，(14)を用い，式(20)，(21)をマトリクス表示すると次式となる.

$$
\left[\begin{array}{cc}
-\left(\frac{K_{T 0} K_{E 0}}{R_{0}}+N_{0}\right) & 2 \omega K \sin \Phi \\
2 \omega K \sin \Phi & \frac{K_{T 2} K_{E 2}}{R_{2}}+N_{2}
\end{array}\right]\left[\begin{array}{l}
\frac{d \xi}{d t} \\
\frac{d \eta}{d t}
\end{array}\right]+\left[\begin{array}{ll}
K \omega^{2} \cos \Phi & -K \omega^{2} \cos \Phi \\
K \omega^{2} \cos \Phi & -K \omega^{2} \cos \Phi
\end{array}\right]\left[\begin{array}{l}
\xi \\
\eta
\end{array}\right]=\left[\begin{array}{l}
0 \\
0
\end{array}\right]
$$

式(22)の解を

$$
\xi=\xi_{0} e^{\lambda t}, \quad \eta=\eta_{0} e^{\lambda t}
$$

とおき，式(22)に代入すると次式を得る.

$$
\left[\begin{array}{cc}
-\left(\frac{K_{\mathrm{T} 0} K_{\mathrm{E} 0}}{R_{0}}+N_{0}\right) \lambda+K \omega^{2} \cos \Phi & 2 \omega K \sin \Phi \cdot \lambda-K \omega^{2} \cos \Phi \\
2 \omega K \sin \Phi \cdot \lambda+K \omega^{2} \cos \Phi & \left(\frac{K_{\mathrm{T} 2} K_{\mathrm{E} 2}}{R_{2}}+N_{2}\right) \lambda-K \omega^{2} \cos \Phi
\end{array}\right]\left[\begin{array}{l}
\xi_{0} \\
\eta_{0}
\end{array}\right]=\left[\begin{array}{l}
0 \\
0
\end{array}\right]
$$

ここで， $\xi_{0}, \quad \eta_{0}$ が自明でない解を持つためには 


$$
\left|\begin{array}{cc}
-\left(\frac{K_{\mathrm{T} 0} K_{\mathrm{E} 0}}{R_{0}}+N_{0}\right) \lambda+K \omega^{2} \cos \Phi & 2 \omega K \sin \Phi \cdot \lambda-K \omega^{2} \cos \Phi \\
2 \omega K \sin \Phi \cdot \lambda+K \omega^{2} \cos \Phi & \left(\frac{K_{\mathrm{T} 2} K_{\mathrm{E} 2}}{R_{2}}+N_{2}\right) \lambda-K \omega^{2} \cos \Phi
\end{array}\right|=0
$$

となる.よって,

$$
\begin{aligned}
\left\{4(K \omega \sin \Phi)^{2}+\left(\frac{K_{T 0} K_{E 0}}{R_{0}}+N_{0}\right)\left(\frac{K_{T 2} K_{E 2}}{R_{2}}+N_{2}\right)\right\} \lambda^{2} \\
-\left\{\left(\frac{K_{T 0} K_{E 0}}{R_{0}}+N_{0}\right)+\left(\frac{K_{T 2} K_{E 2}}{R_{2}}+N_{2}\right)\right\} K \omega^{2} \lambda \cos \Phi=0
\end{aligned}
$$

となる. Routh の安定判別より, 安定条件は次式となる.

$$
4(K \omega \sin \Phi)^{2}+\left(\frac{K_{T 0} K_{E 0}}{R_{0}}+N_{0}\right)\left(\frac{K_{T 2} K_{E 2}}{R_{2}}+N_{2}\right)>0, \quad-\left\{\left(\frac{K_{T 0} K_{E 0}}{R_{0}}+N_{0}\right)+\left(\frac{K_{T 2} K_{E 2}}{R_{2}}+N_{2}\right)\right\} K \omega^{2} \cos \Phi>0
$$

上の式中のパラメータの符号を考えると, 結局, 定常解の安定条件は次式となる.

$$
\cos \Phi<0
$$

また，安定な定常解は次式となる.

$$
a_{1}^{2}=\frac{1}{\left(m_{0}+m_{1}+m_{2}\right)^{2}}\left\{\left(m_{0} l_{G 0}\right)^{2}+\left(m_{2} l_{\mathrm{G} 2}\right)^{2}-2 m_{0} l_{G 0} m_{2} l_{\mathrm{G} 2} \sqrt{1-\sin ^{2}\left(\varphi_{00}-\varphi_{20}\right)}\right\}
$$

\section{$3 \cdot 3$ 最適制振}

最適な制振のためにアシストモータに与える心゙き最適な電圧について考える. 前節の平均法で得られた定 常振幅 $a_{1}$ を 0 とするためには, 式(28)から

$$
\sin \Phi=\sin \left(\varphi_{00}-\varphi_{20}\right)=0
$$

とすればよい. 式(27)の解の安定性も考慮すると, 上式は, $\varphi_{20}=\varphi_{00}+\pi$, すなわち, フラフープとアンバラ ンスの位相差が 180 度の状態にあることを意味する.このとき, 式(13), (14)から電圧 $E_{2}$ の適正值として次式 を得る。

$$
E_{2}=\frac{K_{E 2}+\frac{R_{2}}{K_{T 2}} N_{2}}{K_{E 0}+\frac{R_{0}}{K_{T 0}} N_{0}} E_{0}=\omega\left(K_{E 2}+\frac{R_{2} N_{2}}{K_{T 2}}\right)
$$

主系のモータに与える電圧 $E_{0}$, あるいは, 角振動数 $\omega$ に応じて, 上式で与えられる電圧 $E_{2}$ をシストモータ に供給すれば主系の振幅は近似的に零になる.

\section{4. 数值解析結果}

前章で示した平均法の解析結果を用いて近似解を求めるとともに, ルンゲ・クッタ・ギル法を用いて数值 
積分を行うことにより定常解を求める.

\section{$4 \cdot 1$ 数值解析パラメータ}

主系，アンバランス，フラフープの各パラメータを以下に示す．これらは次の章で示す実験装置の值であ る. 動力源モータとアシストモータはそれぞれ澤村電気社製 DC モータ SS32F，マブチモーター社製 DC モ ータ RE-280RA であるが，これらのパラメータはカタログ值を用いている.

$<$ 主系 $>$

$$
m_{1}=8.34 \times 10^{-1}[\mathrm{~kg}], \quad c_{1}=1.930 \times 10^{-1}[\mathrm{Ns} / \mathrm{m}], \quad k_{1}=2.11 \times 10^{3}[\mathrm{~N} / \mathrm{m}]
$$

<アンバランス >

$$
m_{0}=2.16 \times 10^{-2}[\mathrm{~kg}], \quad l_{G 0}=2.0 \times 10^{-2}[\mathrm{~m}], \quad I_{G 0}=3.129 \times 10^{-6}\left[\mathrm{kgm}^{2}\right]
$$

$<$ フラフープ $>$

$$
m_{2}=2.16 \times 10^{-2}[\mathrm{~kg}], \quad l_{G 2}=2.0 \times 10^{-2}[\mathrm{~m}], \quad I_{G 2}=3.129 \times 10^{-6}\left[\mathrm{kgm}^{2}\right]
$$

$<$ 動力源モータ $>$

$$
\begin{aligned}
& I_{G M 0}=4.40 \times 10^{-5}\left[\mathrm{kgm}^{2}\right], \quad L_{0}=4.40 \times 10^{-3}[\mathrm{H}], \quad R_{0}=3.8[\Omega] \\
& K_{E 0}=5.85 \times 10^{-2}[\mathrm{Vs} / \mathrm{rad}], \quad K_{T 0}=5.85 \times 10^{-2}[\mathrm{~N} \cdot \mathrm{m} / \mathrm{A}], \quad N_{0}=3.44 \times 10^{-5}[\mathrm{Nms} / \mathrm{rad}] \\
& <\text { アシストモータ }> \\
& I_{G M 2}=0\left[\mathrm{kgm}^{2}\right], \quad L_{2}=2.0 \times 10^{-3}[\mathrm{H}], \quad R_{2}=1.0[\Omega] \\
& K_{E 2}=2.80 \times 10^{-3}[\mathrm{Vs} / \mathrm{rad}], \quad K_{T 2}=2.80 \times 10^{-3}[\mathrm{Nm} / \mathrm{A}], \quad N_{2}=1.03 \times 10^{-5}[\mathrm{Nms} / \mathrm{rad}]
\end{aligned}
$$

\section{$4 \cdot 2$ 数值解析結果}

図 4 に共振曲線を示す. 縦軸は主系の変位振幅, 横軸は主系の振動数である. 数值計算結果として, フラ フープが効果的な共振点 $(7.90 \mathrm{~Hz})$ より高い振動数領域（15Hz 以上）の結果を示している. 平均法による安定 定常解を実線で示している，黒の実線はフラフープを取り付けていない場合の解 (Without H.H.), 赤の実線 はアシストモータに電圧を供給することなく, 初速のみ与えることによりモータによるアシストなしでフラ フープを回転させた場合の解 (Rotating Without Assist), 青の実線は式(30)で与えられる最適な電圧をアシス トモータに与えた場合の解（Rotating With Assist）を表している．また，ルンゲ・クッタ・ギル法による解を それぞれの場合について丸印で示している.ルンゲ・クッタ・ギル法による解のうち，アシストがある場合 の解は動力源モータに与える電圧毎に, 主系の振幅が最小となるようにアシストモータに与える電压 $E_{2}$ を試 行錯誤で求め, そのときの主系の振幅をプロットしている. 図 4 において平均法による解とルンゲ・クッタ・ ギル法による解はフラフープがない場合を除き，よく一致している．平均法による解は，フラフープがない 場合には主系の復元力と減衰力を省略した影響が大きく, ルンゲ・クッタ・ギル法による解との差が大きく なっているが，他の場合はよい近似となっていることがわかる. 制振効果については, 前報(7)と異なりアシ ストなしでフラフープを回転させた場合の制振効果がそれほど大きくないが，これはアシストなしの時でも， 電圧をかけないものの, アシストモータをフラフープに接続しているために, 回転抵抗が大きくなったため

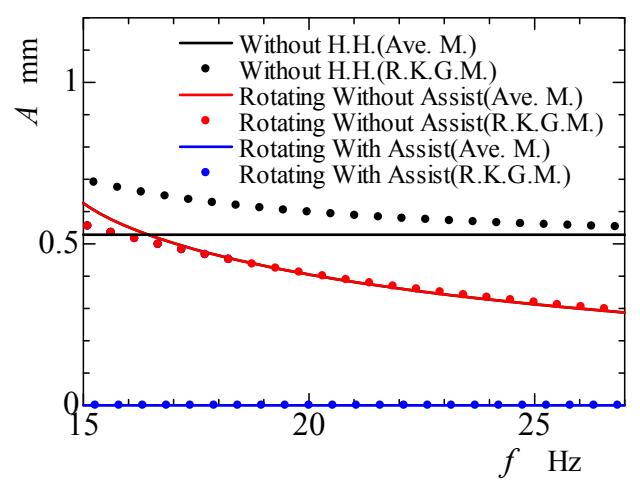

Fig.4 Resonance curve

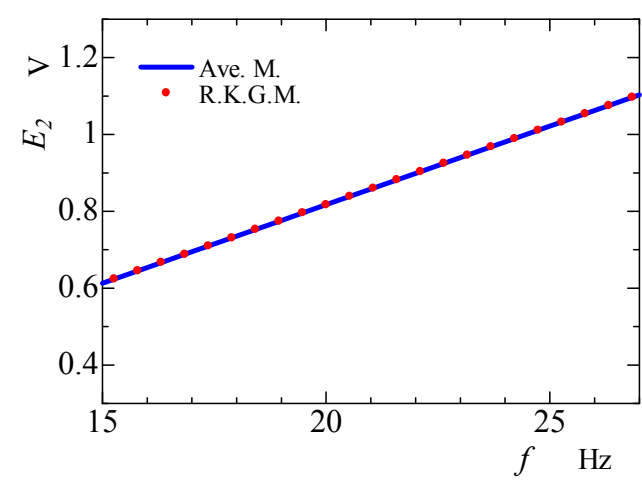

Fig.5 Optimum voltage 


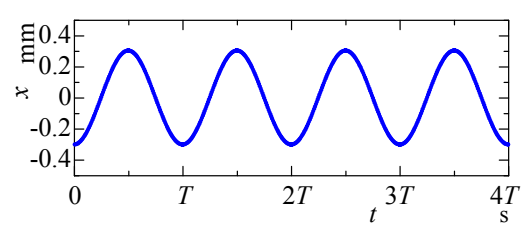

(a) Main system

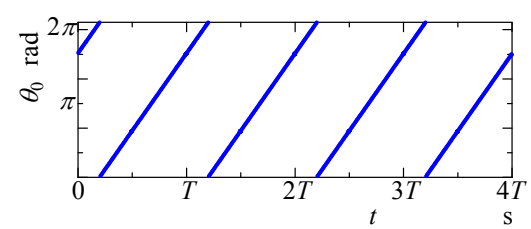

(b) Unbalance

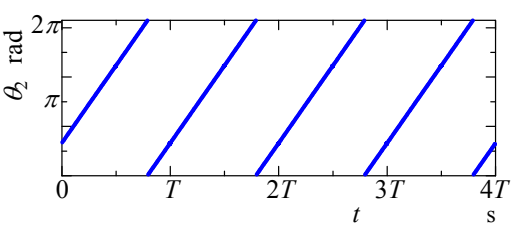

(c) Hula-Hoop

Fig.6 Waveforms (Rotating without assist, 25Hz)

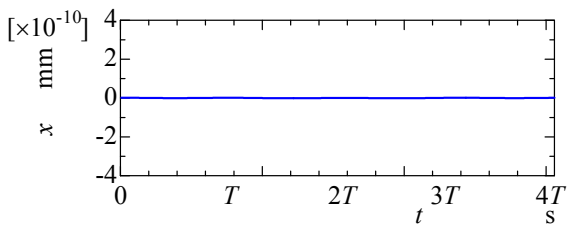

(a) Main system

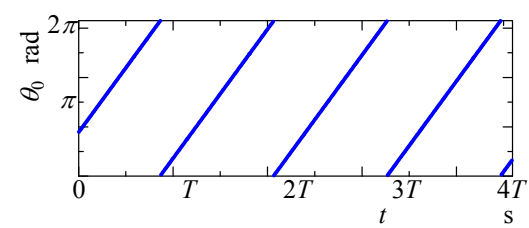

(b) Unbalance

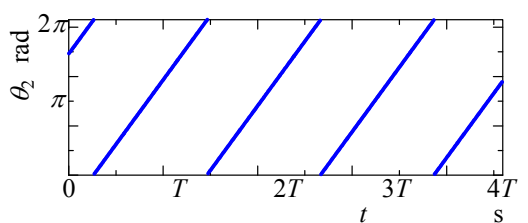

(c) Hula-Hoop

Fig.7 Waveforms (Rotating with assist, 25Hz)

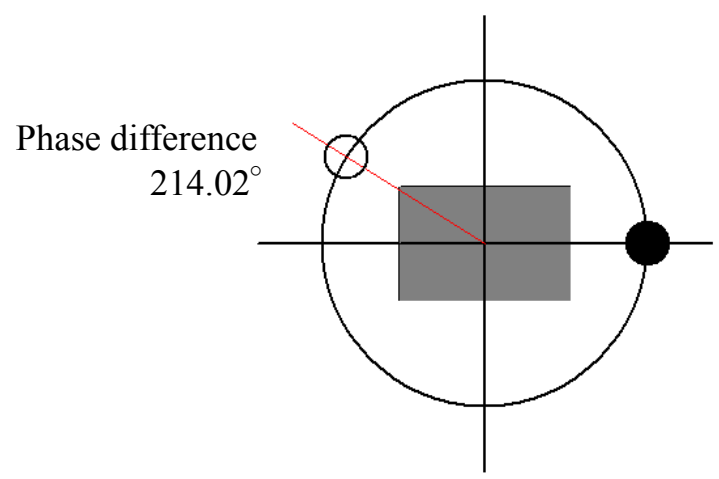

(a) Rotating without assist $(25 \mathrm{~Hz})$

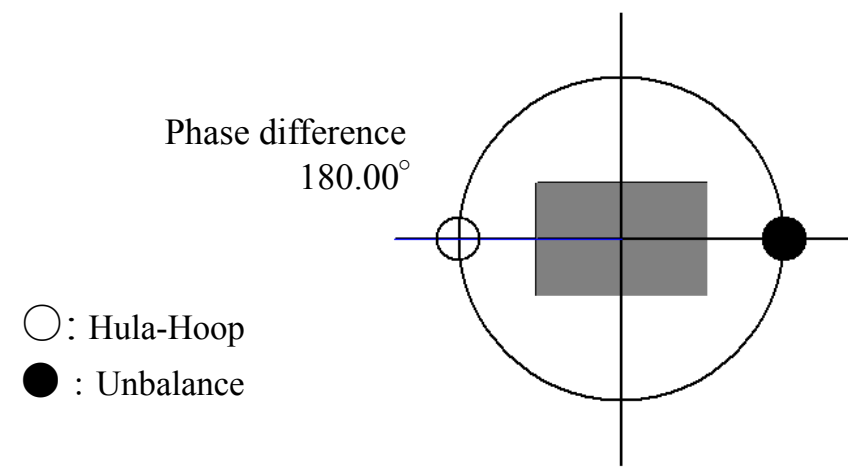

(b) Rotating with assist $(25 \mathrm{~Hz})$

Fig.8 Positions of unbalance and Hula-Hoop

である.アシストがある場合の解は図 4 の全ての振動数において振幅がほぼ 0 となっている.アシストモー 夕に与える電圧 $E_{2}$ が最適でない場合, 振幅は 0 とはならない.

図 5 にアシストモータに与える適正電圧と振動数の関係を示している. 実線は平均法から得られた式(30) で与えられる最適な電圧を示している．また，前述のようにルンゲ・クッタ・ギル法を用いて主系の振幅が 最小となるようにアシストモータに与える電圧 $E_{2}$ を試行錯誤で求めたときの適正電圧を赤色の丸印で示して いる．両者の結果は定量的によく一致している.

図 6 にアシストなしでフラフープを回転させた場合（Rotating Without Assist）の 25Hzにおける主系，アン バランス，フラフープの波形を示寸．縦軸はそれぞれ主系の変位，アンバランスの回転角，フラフープの回 転角であり，横軸はいずれも主系の振動周期 $T$ の 4 周期間を示している. また，図 7 にアシストがある場合

(Rotating With Assist）の 25Hz における同様の波形を示している.さらに，図 6 と図 7 の各場合のアンバラ ンスの角度 $\theta_{0}$ とフラフープの角度 $\theta_{2}$ の相対的位置関係を図 8 に示している.これらの図はルンゲ・クッタ・ ギル法を用いて計算したものである，アシストがない場合，アンバランスとフラフープは位相差が $214.02^{\circ}$ の状態でほぼ一定角速度で回転していることがわかる．これはフラフープに作用寸る回転抵抗の影響である. アシストがある場合, アンバランスとフラフープは位相差が $180.00^{\circ}$ の状態でほぼ一定角速度で回転しており， 主系の振幅はほぼ 0 であることがわかる.

\section{$5 \cdot 1$ 実験装置}

\section{5. 実 験}

図 9 に実験装置を示す。主系は動力源モータが取り付けられたアルミ製の長方形の厚板が 4 本のアルミ製 
の板ばねによって支持された一自由度系である. 動力源モータにはアンバランスが取り付けられており, 動 力源モータに電圧を与えるとアンバランスは水平面内で回転する. また，主系の上部には，フラフープとア シストモータからなる制振装置が太い柱を介して取り付けられている. 動力源モータ, アシストモータとし て，以下に示す市販の DC モータを用いる.

動力源モータ：澤村電気工業社製 DC モータ SS32F（定格２4.0V，1.4A，3000rpm，6.4mNm）

アシストモータ:マブチモーター社製DCモータ RE-280RA-2865(定格 $1.85 \mathrm{~V}, 0.87 \mathrm{~A}, 7700 \mathrm{rpm}, 1.98 \mathrm{mNm}$ ) 動力源モータとアシストモータのそれぞれの定格電圧におけるトルク特性（カタログ值）を図 10 に示す.

定電圧発生装置を用いて動力源モータに電圧 $E_{0}$ をちえ, アンバランスを回転させることにより主系の水平 方向に遠心力型の外力を作用させる. 主系の変位は加速度ピックアップを用いて計測した．また，アシスト モータに与える電圧 $E_{2}$ も計測した. 実験は, フラフープを取り付けていない場合 (Without H.H.), アシスト モータに電圧をかけずフラフープに初期速度を与えることによりフラフープを回転させる場合（Rotating Without Assist)，アシストモータに電圧をかける場合（Rotating With Assist）の3つの場合の実験を行った. ア シストモータにかける最適電圧の決定方法は, 各振動数において, 主系の振幅が最小となるようアシストモ

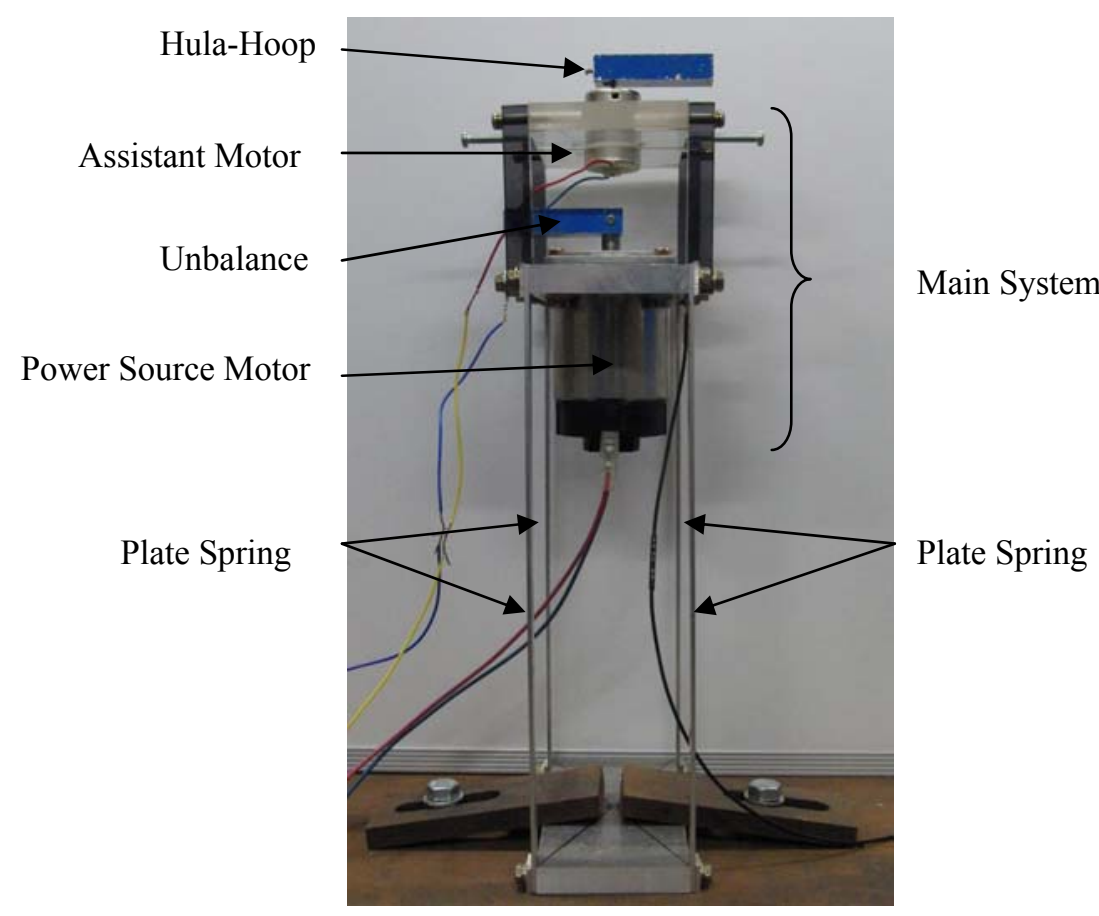

Fig.9 Experimental apparatus

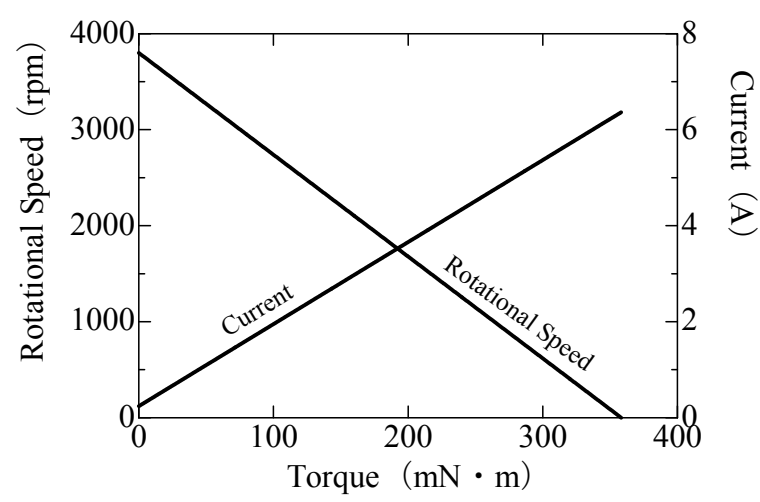

(a) Power source motor $(24.0 \mathrm{~V})$

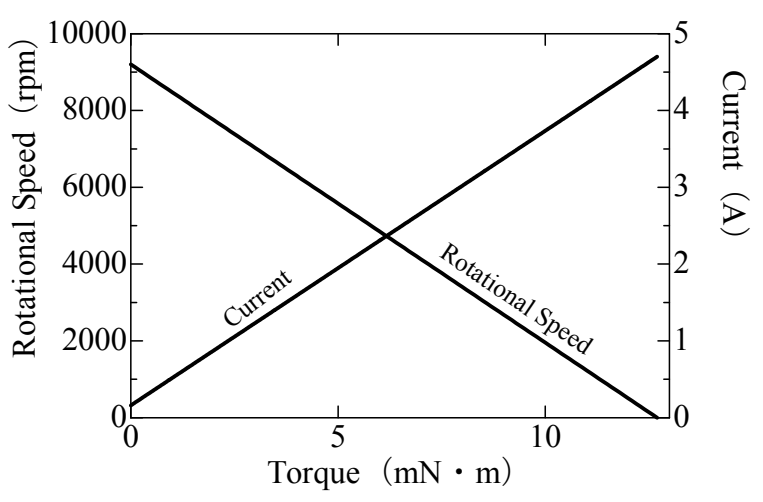

(b) Assistant motor (1.85V)

Fig.10 Torque characteristic of motors 


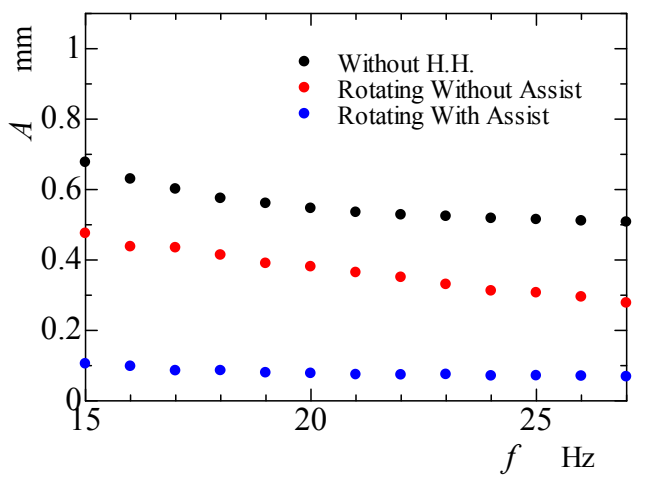

Fig.11 Resonance curve

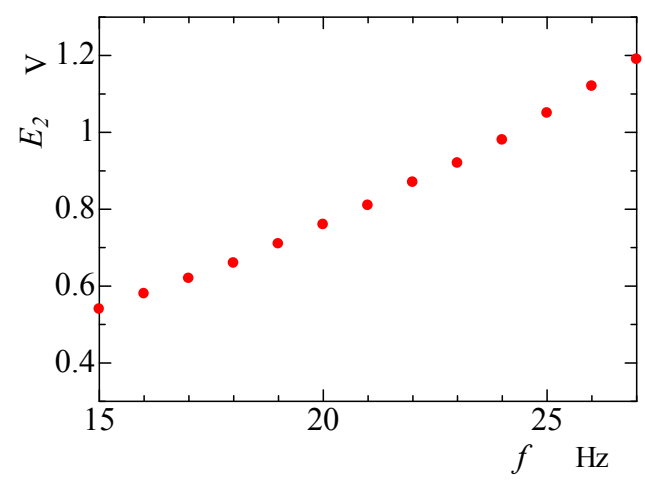

Fig.12 Optimum voltage

一タにかける電圧を試行錯誤で求め, それの電圧を最適電圧とする.すなわち, 数值計算におけるルンゲ・ クッタ・ギル法による最適電圧の決定法と同様である.

\section{$5 \cdot 2$ 実験結果}

図 11 に実験で得られた共振曲線を示す。縦軸は主系の変位振幅，横軸は主系の振動数である. 対象とした 振動数領域は主系の共振点より高い $15 \mathrm{~Hz} 27 \mathrm{~Hz}$ である. アシストモータ用の定電圧発生装置の供給電力の容 量から振動数は $27 \mathrm{~Hz}$ までとした. 黒, 赤, 青の各丸印はそれぞれフラフープを取り付けていない場合 (Without H.H.), アシストモータに電圧をかけずにフラフープを回転させた場合（Rotating Without Assist）, アシストモ ータに適正電圧をかけフラフープを回転させた場合（Rotating With Assist）の共振曲線である.

図 11 の実験結果を図 4 の数值計算結果と比較する. Without H.H.と Rotating Without Assist は数值解析結果 と実験結果が定性的だけでなく, 定量的にもある程度一致する結果となっている. しかし, Rotating With Assist については数值計算結果と異なり主系の振幅はほぼ零にはなっていない.アシストモータにかける電圧を調 節しても図示した振幅が最小であった。これは図 9 の実験装置の図に示寸ようにフラフープを取り付けてい る高さ方向の位置がアンバランスと同じ位置ではないためにフラフープがアンバランスと完全にバランスす ることができなかったためと推察される.

図 12 にアシストモータに与えた最適電圧と振動数の関係を示している. 図 12 の実験結果は図 5 の数值計 算結果と定性的に良く一致していることがわかる.

\section{6. 結 言}

有限の動力源によりアンバランスが回転することで振動する一自由度振動系をフラフープとアシストモー タからなる装置を用いて制振する問題について, 平均法による近似解析, 数值積分, および実験を行なって 調べた結果は以下のようにまとめられる.

(1) アシストモータによりフラフープの回転抵抗を打ち消すことにより, 共振点より高い振動数領域におい て，主系の振幅を理論的にはほぼ零にできる.

（2）動力源とアシスト装置がモータの場合について，最適な制振のためにアシストモータにかけるべき電圧 を平均法による近似解析から求めた.

（3）平均法による近似解析結果と数值積分による結果は定性的だけでなく，定量的にも一致し，それらの結 果と実験の結果は定性的に一致した.

\section{文献}

（1）井上順吉, 陣内靖介, 荒木嘉昭, 中原章, “自動平衡装置（その基礎的な特性）”, 日本機械学会論文集 C 編, Vol.45, No.394(1979), pp.646-652.

（2）井上順吉, 陣内靖介, 久保省蔵, “自動平衡装置（動不つりあい一の適用)”, 日本機械学会論文集 C 編, Vol.49, No.448 (1983), pp.2142-2148.

（3）吉武裕, 末岡淳男，福島明寿，山脇勝也，赤峰秀樹，“機械・構造物の制振と発電を同時に行う装置の研究（強 
制一自由度系の制振）”, 日本機械学会論文集 C 編, Vol.66, No.650(2000), pp.3233-3241.

(4) Yoshitake, Y., Ishibashi, T. and Fukushima, A., "Vibration control and electricity generating device using a number of hula-hoops and generators", Journal of Sound and Vibration, Vol.275, No.1-2(2004), pp.77-88.

(5) 吉武裕, 末岡淳男, 森山智樹, 山崎正則, “フラフープを用いた自励振動の制振と発電”, 日本機械学会論文集 C 編, Vol.66, No.646(2000), pp.1785-1792.

(6) Yoshitake, Y., Sueoka, A., Yamasaki, M., Sugimura, Y. and Ohishi, T., "Quenching of vortex-induced vibrations of towering structure and generation of electricity using Hula-Hoops", Journal of Sound and Vibration, Vol.272, No.1-2, (2004), pp.21-38.

（7）吉武裕, 原田晃, 柴田佳紀, 永代行日出, 梶原修平, “フラフープを用いた制振装置“, 日本機械学会論文集 C 編, Vol.76, No.766( 2010), pp.1483-1488.

（8）吉武裕，清水亮佑，柴原文高，梶原修平，濱田知宏，原田晃，“フラフープを用いた機械構造物の制振（鉛直方 向振動と水平方向振動の比較，および制振効果）“，日本機械学会論文集 C 編投稿中. 